\title{
PACIFIC NORTHWEST LABORATORY MONTHLY ACTIVITIES REPORT OCTOBER 1974
}

Division of Production and Materials Management and Hanford Plant Assistance Programs

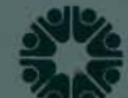 \\ Battelle}

Pacific Northwest Laboratories

Richland, Washington 99352

NOVEMBER 1974

Prepared for the U.S. Atomic Energy Commission under Contract AT(45-1):1830 


\title{
NOTICE
}

This report was prepared as an account of work sponsored by the United States Government. Neither the United States nor the United States Atomic Energy Commission, nor any of their employees, nor any of their contractors, subcontractors, or thier employees, makes any warranty, express or implied, or assumes any legal liability or responsibility for the accuracy, completeness or usefulness of any information, apparatus, product or process disclosed, or represents that its use would not infringe privately owned rights.

\author{
PACIFIC NORTHWEST LABORATORY \\ operated by \\ BATTELLE \\ for the \\ U.S. ATOMIC ENERGY COMMISSION \\ Under Contract AT(45-1)-1830
}

\author{
Printed in the United States of America \\ Available from \\ National Technical information Service \\ U.S. Department of Commerce \\ 5285 Port Royal Road \\ Springfield, Virginia 22151 \\ Price: Printed Copy \$5.45; Microfische \$2.25
}


BNWL -1880

UC -2

Special

Distribution

PACIFIC NORTHWEST LABORATORY

MONTHLY ACTIVITIES REPORT

OCTOBER 1974

Division of Production and Materials Management

and

Hanford Plant Assistance

Programs

by the

Staff of Battelle-Northwest

E. L. Alpen, Director

NOVEMBER 1974

BATTELLE

PACIFIC NORTHWEST LABORATORY

RICHLAND, WASHINGTON 99352 


\section{TABLE OF CONTENTS}

Page No.

Assistance to Atlantic Richfield Hanford Company - Summary. . . . . 3

Assistance to Atlantic Richfield Hanford Company. . . . . . . . . 5

Technical Assistance to the Hanford Plant - Summary . . . . . . 11

Technical Assistance to the Hanford Plant . . . . . . . . 12 


\author{
PACIF IC NORTHWEST LABORATORY \\ MONTHLY ACTIVITIES REPORT \\ DIVISION OF PRODUCTION AND MATERIALS MANAGEMENT \\ AND HANFORD PLANT ASSISTANCE PROGRAMS \\ ASSISTANCE TO ATLANTIC RICHFIELD HANFORD COMPANY \\ Summary \\ PROCESS DEVELOPMENT - RESEARCH DEPARTMENT
}

Studies are in progress toward developing reliable operating control instrumentation for an air filter array used in resuspension studies.

\title{
PROCESS TECHNOLOGY - RESEARCH DEPARTMENT
}

Tank Farm Support

Characterization of sediment samples from $T$ and $S$ tank farms as to bulk and particle density, hydraulic conductivity, and fluid retentivity has been completed.

\section{Prevention of Accidental Releases}

- Surficial Contamination and Airborne Release Studies

Additional samples were processed to complete the experiments on potential release of CS-137 during cleaning of surface material from the B-C crib area.

The basic formulation of the surface flux model, which incorporates the Gaussian plume model, was verified with an exact solution of the problem for the special case of constant eddy diffusivity. This agreement gave assurance that the basic formulation and programming was correct.

Samples of soil gathered from typically contaminated U-pond areas were analyzed. The results will be used in extending analyses more meaningfully to other samples collected in the vicinity. 


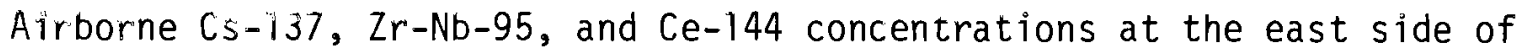
$\mathrm{U}$-pond were essentially constant for heights up to 30 meters during March 21 to May 20, 1974.

The transport and diffusion program was thoroughly checked against the continuous plume model for a steady wind. A study was initiated to compare downwind doses calculated from the model and doses calculated assuming source winds.

- Groundwater Management

New well elevation surveys were entered into the data storage and retrieval systems.

Water elevation measurements in the BNW monitored wells were taken during October 14-16.

\section{PROCESS TECHNOLOGY - DEVELOPMENT ENGINEERING DEPARTMENT}

Storage of High-Level Liquid Wastes

\section{Leak Detection}

Initial tests with the breadboard ultrasonic logging system installed in Tank il1S indicate liquid levels can be located accurately and that it is possible to detect the depth of liquid over sludge or salt cake.

In other: liquid level measurement studies, a 33-ft probe containing four sensors for various electronic measurements was inserted in Tank 111S.

For external measurements to detect tank leaks, connections to three underground waste tanks and adjacent wells have been made in preparation for $A C$ impedance, DC potential and short-circuit current measurements. 
. $-5-\quad$ BNWL -1880

\section{ASSISTANCE TO ATLANTIC RICHFIELD HANFORD COMPANY}

PROCESS DEVELOPMENT - RESEARCH DEPARTMENT

Control Instrumentation for Resuspension Studies

(0. H. Koski, Chemical Development Section)

Control instrumentation is being developed to select and operate, as a function of wind speed and direction, filters used in radioactivity resuspension studies. Five different filters are used to provide data on particle resuspension at five different wind speeds provided the wind direction is within a given sector.

Two different instrumentation systems are being considered. A commercially available system in use became inoperable due to wind direction logic failure. An instrumentation device was developed to provide an identical control function until necessary replacement parts can be obtained from the manufacturer.

\section{PROCESS TECHNOLOGY - RESEARCH DEPARTMENT}

\section{$\underline{\text { Tank Farm Support }}$}

Hydraul ic Properties of Hanford Sediments (S.J. Phillips, Resource Systems Section)

Characterization of sediment samples from $T$ and $S$ tank farms, as to bulk and particle density, hydraulic conductivity, and fluid retentivity is complete. Data collected from TX, B, A, SX and TY tank farm sediment samples are being coded for computer input into the physical characteristics section of the data base. The Gould electrostatic printer and computer software system has arrived and is being interfaced to the PDP-11/45 computer. Data wi1l be displayed in the requested format during the next reporting period.

Characterization of Hanford sediments as to hydraulic parameters is part of the ARHCO Physical and Life Sciences Geology program。

Prevention of Accidental Releases

- Surficial Contamination and Airborne Release Studies 
B-C Crib Studies

(J. Mishima and L. C. Schwendiman, Particulate and Gaseous Waste Research Section)

Potential Airborne Release of Contaminated Surface Material During Heating

Experiments to determine the fractional release of $\mathrm{Cs}-137$ and $\mathrm{Sr}-90$ during charring of contaminated materials from the $B-C$ crib were essentialiy completed. Some samples were repeated to confirm results.

Safety Analysis of B-C Area Contamination

The basic formulation and computer implementation of the surface flux model, incorporating the Gaussian plume model, was verified by comparison with an exact solution of the problem for the special case of a constant eddy diffusivity. The agreement of these two solutions has shown that the negative air concentration results reported last month were not inherent to the use of the Gaussian plume model or to the deposition velocity parameterization of the lower boundary condition. Rather they were caused by the particular form used for the diffusion coefficients. These are a consequence of fitting the vertically homogeneous Gaussian plume model to experimental diffusion data. It is planned to replace the Gaussian plume model with one based on Lagrangian similarity, which should more realistically reproduce diffusion near the ground.

\section{U-Pond Contamination Studies}

(L. C. Schwendiman and J. Mishima, Particulate and Gaseous Waste Studies)

Soil samples from three locations near the joining point of three ditches with the U-pond were analyzed for the principal isotopes anticipated. The results will be used to determine the analyses to be performed on several more samples taken in the $\mathrm{U}$-pond area.

Resuspension from Contaminated Surfaces - Field Studies

(G. A. Sehmel, F。D.Lloyd and L. C. Schwendiman, Particulate and Gaseous Waste Research Studies)

Initial radiochemical results were received for the 8 in. $x 10$ in. air filters mounted on a $30 \mathrm{~m}$ tower at the U-pond. These filters sampled all west winds blowing from 170 to $340^{\circ}$ during March 21 to May 20, 1974. Fi1ters were mounted at $0.3,1,3,4,11$, and $30 \mathrm{~m}$ elevations. 
Airborne concentrations were generally uniform for heights from 0.3 to $30 \mathrm{~m}$ for $\mathrm{Cs}-137$ (5 to $\left.6 \times 10^{-15} \mu \mathrm{Ci} / \mathrm{cm}^{3}\right), \mathrm{Zr}-95\left(2\right.$ to $\left.3 \times 10^{-15} \mu \mathrm{Ci} / \mathrm{cm}^{3}\right), \mathrm{Ce}-144$ (2 to $\left.3 \times 10^{-14} \mu \mathrm{Ci} / \mathrm{cm}^{3}\right)$, and $\mathrm{Nb}-95\left(5\right.$ to $\left.6 \times 10^{-15} \mu \mathrm{Ci} / \mathrm{cm}^{3}\right)$. Maximum concentrations were observed at $1 \mathrm{~m}$ height for $\mathrm{Ce}-144$ and at $10 \mathrm{~m}$ height for $\mathrm{Nb}-95$, but it is doubtful if these represent significant differences from the averages. The release guides to uncontrolled areas for the above listed radionuclides are: $\mathrm{Cs}-137\left(5 \times 10^{-10} \mu \mathrm{Ci} / \mathrm{cm}^{3}\right), \operatorname{Zr}-95\left(1 \times 10^{-9} \mu \mathrm{Ci} / \mathrm{cm}^{3}\right), \mathrm{Ce}-144\left(2 \times 10^{-10} \mu \mathrm{Ci} / \mathrm{cm}^{3}\right)$ and $\mathrm{Nb}-95\left(3 \times 10^{-9} \mu \mathrm{Ci} / \mathrm{cm}^{3}\right)$.

Air filters west and upwind of $U$-pond were operated simultaneously, but as a function of wind speed at 1 and $3 \mathrm{~m}$ heights. Airborne concentrations of Cs-137, Ce-144 and Nb-95 all increased with an increase in windspeed. In each case, the average upwind concentration was about twice the downwind concentration. In previously reported data, downwind concentrations have always exceeded upwind concentrations. Increased downwind concentration would be attributed to resuspension of contamination from the vicinity of the U-pond.

One additional $\mathrm{Pu}$ analysis has been received for $\mathrm{U}$-pond for August 20 to September 10, 1973. This sample indicates an airborne concentration of $6.9 \times 10^{-17} \mu \mathrm{Ci} / \mathrm{cm}^{3}$ which is comparable to the average of $1.16 \times 10^{-16} \mu \mathrm{Ci} / \mathrm{cm}^{3}$ (76 to 184 range) for the previous time period of August 20 to September 10, 1973. Plutonium has been identified in all seven air filter samples so far analyzed. The release guide to uncontrolled areas for $\mathrm{Pu}-239$ is $6 \times 10^{-14} \mu \mathrm{Ci} / \mathrm{cm}^{3}$.

An instrument is being used to pre-assess additional filters prior to detailed Pu analysis. This instrument consists essentially of a zinc sulfide phosphor sheet attached to a photomultiplier tube and placed adjacent to a filter. Counts on the photomultiplier tube are much greater than can be attributed to either the a from $\mathrm{Pu}$ on one filter or the uranium on the filter. The source of counts from the zinc sulfide is being sought.

Wind Trajectory Studies (L. L. Wende11, Atmospheric Physics Section)

Preparation for the numerical diffusion experiment was resumed. The transport and diffusion program has been thoroughly tested and checked against the continuous plume model for a steady wind. The experiments will consist of computing the exposure patterns, resulting from the same hypothetical continuous release but using transport determined from a wind field, on one hand, and the source wind only, on the other. The wind data will be for the three-week period in Apri1-May 1973. A computer program for determining the diffusion stability 
categories and the mixing depths was developed during this reporting period and will be used to generate this type of input data for the transport and diffusion program.

\section{- Groundwater Management Studies}

Groundwater Model and Data Storage and Retrieval

(K. L. Kipp, D。 R。 Friedrichs and A. E. Reisenhauer, Resources system Section)

Review and updating of the model documentation is underway. Entry of newly surveyed well elevations into the data storage system was completed.

Field Measurement and Monitoring Assistance

(K. L. Kïpp and V.L. McGhan, Resources Systems Section)

The responsibility for monitoring water table elevations is now being shared with the ARHCO Physical and Life Science Section. Water elevations were measured during the period 0ctober 14 to 16 in the Hanford Reservation wells monitored by BNW's Resources Systems Section.

Responsibility for monitoring the moisture content of the lysimeter soil was assumed by ARHCO during the first week in October; at that time the neutron probe equipment was also transferred to ARHCO.

\section{PROCESS TECHNOLOGY - DEVELOPMENT ENGINEERING DEPARTMENT}

\section{Storage of High-Level Liquid Wastes}

\section{Leak Detection}

U1trasonic Logging Liquid Level Measurement (G.J. Posakony and $J, C$. Crowe, Nondestructive Testing Section)

The ultrasonic log "wet wells" have been installed in tank $111 \mathrm{~s}$ in the 200-West Area tank farm and initial field tests have begun. Three "wet wel1s" were installed in existing tank risers; only two of the wells are available for testing due to an obstruction within one. Efforts are currently underway to remove the obstruction. The two operational "wet we11s" are located in risers approximately 15 feet apart near the center of the tank. Initial tests with the breadboard ultrasonic logging system have been encouraging. A significant ultrasonic signal has been transmitted across approximately 15 feet of concentrated 1 iquid wastes in tank 111s. This amount of signal transmission 
should be sufficient for making accurate liquid level measurements. Early tests indicate that signal amplitude detection can be used to detect the liquid-air interface and thereby the liquid level in the tank.

When the transmitter and receiver ultrasonic probes were lowered, in 1/8-in. increments, from about 1/2-in. above to 1/2-in. below the 1iquid-air interface, a significant increase in the signal amplitude occurred at the interface. Such tests indicate that liquid level measurements with an accuracy of $1 / 8-i n$. are possible with a properly designed ultrasonic logging system.

Tank $111 \mathrm{~S}$ was selected for these tests because it is an active storage tank in which the liquid level may fluctuate on a day to day basis. Apparent slight liquid level variations have been observed with the ultrasonic logging system and have been confirmed by FIC gauge readings. The amount of level change detected by the two independent systems agreed to within approximately 0.1 inches. Further tests are planned in the next few weeks to confirm the liquid level measuring capability of the ultrasonic logging system and to obtain a more absolute correlation of FIC gauge vs. ultrasonic log liquid level measurements. A11 comparisons of FIC vs. ultrasonic log data to date have been on a relative basis only.

Tests were also made to determine the capabilities of the ultrasonic logging system for determining the subsurface characteristics of the waste material. Although the separation distance between the ultrasonic probes is greater than desired (approximately 15 feet), ultrasonic thru-transmission measurements have been made at depths down to the lower limit of the "wet we11s" (approximately 4-1/2 feet below the apparent 1iquid surface). Significant variations in signal attenuation were noted at various depths beneath the liquid surface. An increased attenuation of the ultrasonic signal, possibly due to the presence of salt cake or sludge, occurred at about $3 \mathrm{ft}$ below the liquid-air interface in this particular tank. These results indicate that pockets of interstitial liquid can be detected by an ultrasonic logging system. Further tests will be run when the third "wet we11" is made usable for testing.

After minor modifications, operation of the breadboard electronic system is now satisfactory. The logging system is limited in accuracy, repeatability, 
and convenience due to the manual probe positioning mechanisms. These positioning devices should be sufficient for feasibility tests, but they will 1 imit the accuracy of the test data. The transducers and positioning devices have been, on at least one occasion, removed from the "wet wel1s" for repair. A rigorous examination by $A R H C O$ radiation monitoring personnel revealed no radioactive contamination of the probes or positioning devices. This points out a definite advantage of the ultrasonic logging, sealed "wet we11" concept.

Electronic Liquid Level Detection (0. H. Koskï, Chemical Development Section)

A 33-ft probe containing four sensors for various electronic measurements to determine liquid level was delivered and installed in Tank 111S. Additional effort required before data generation can begin includes calibration of the sensors and read-out instrumentation and field assembly of the automatic data recording instruments.

Tank Leak Detection by External Measurements (0. H. Koski, Chemical DeveTopment Section)

Several underground waste storage tanks in the BX, BY and $C$ tank farms have been selected for leakage surveillance by AC impedance, DC potential and short-circuit current measurements between the tanks and adjacent monitoring wells. Electrical connections have been made on three tanks and adjacent wel1s. Initial measurements will be made by BNW personnel and the system will then be operated by ARHCO. 


\section{TECHNICAL ASSISTANCE TO THE HANFORD PLANT}

\section{Summary}

\section{Environmental Evaluations}

Several groundwater sampling wells have been returned to the routine sampling schedule after structural modifications. Additional routine river samples from the 300 Area are being analyzed following the switch of 300 Area process water from the north to the south process pond. Hanford and Washington State background radiation measurements at Richland agreed within practical 1 imitations for the first nine months of 1974.

\section{Radiation Protection}

Recalibration of nuclear accident dosimeters for the $10-10,000 \mathrm{R}$ range was initiated.

A proposal for quality control and associated engineering studies for the personnel dosimeter program was initiated.

\section{Radiation Standards and Engineering}

The vendor qualification step of the CP procurement plan should be completed this month. Restandardization of the calibration fields to BNS is continuing. 


\section{TECHNICAL ASSISTANCE TO THE HANFORD PLANT}

\section{(J. P. Corley, Environmental Evaluations Section)}

Several groundwater monitoring wells were returned to the routine sampling schedule following modifications to eliminate the possibility of sampling stagnant water columns.

The 300 Area process water was switched from the north to the south process pond during September. Since it is known that the south pond has a much shorter groundwater flow path and, hence, travel time to the Columbia River than the north pond, additional routine river samples are being collected at the 300 Area and analyzed.

Al1 routine road, railroad, and aerial surveys were completed with no unusual measurements except the detection of a $20,000 \mathrm{c} / \mathrm{m}$ particle on the east side of the 200-East Area. Several waste disposal sites were surveyed; at a few sites dense vegetation growth has been allowed to accumulate. The responsible contractors have been contacted.

The Richland location of Washington State penetrating radiation monitoring network was changed to the 747-A Building from the Richland Airport to coincide with our routine Richland Monitoring station. Both programs use thermoluminescent dosimeters but of a different type. Comparison of data for the first nine months of 1974, with the State dosimeter at the Richland Airport, showed an insignificant difference of $0.01 \mathrm{mR} /$ day $(0.19 \mathrm{vs}, 0.78)$.

$$
\text { (K. R. Heid, Personnel Dosimetry Section) }
$$

AECM-0545 requires our nuclear accident (criticality) dosimeters to be capable of gamma dose measurement between 10R and 10,000R. This range is within the capability of our criticality dosimeter, but our calibration only covered $10 R$ to $5,000 R$. Recalibration for the broader range was initiated.

A proposal for quality control and associated engineering studies for the personnel dosimeter program was submitted to RL-AEC at their request. This program identifies efforts required to bring the program up to an acceptable level of performance and for an on-going program thereafter. 
$A$ recent $R L-A E C$ appraysal of criticality dosimetry program identified needs that exist. Responsibility for coordination of a Hanford-wide program had not been identified by RL-AEC since de-centralization had been implemented. However, BNW had informally kept the former program going adequately enough to meet AECM-0545 requirements. Responsive to RL-AEC's request, BNW has submitted a proposal to carry on the over-all coordination effort for this program at Hanford including replacement of the existing dosimeters.

\section{Radiation Standards and Engineering \\ (J. M. Selby, Radiation Standards and Engineering Section)}

Technical evaluation of the prototype CPS is continuing. Evaluation of the quality assurance program of potential suppliers should be completed during October. Suppliers meeting the requirements of the technical proposal will be asked to submit bids for new CPS,

A series of three pocket sized electronic dosimeters was evaluated for possible use at Hanford. The series consisted of two dose rate devices and one dose integrater. Performance was marginal on all three instruments and completely unreliable on one. This work makes a total of four pocket sized electronic dosimeters that have been evaluated in recent months - all with disappointing results.

\section{Meteorological Services}

(E. H. Phinney, Synoptic Meteorology Section)

Meteorological services, viz., weather forecasts and observations and climatological services were provided to plant operations and management on a routine basis.

\section{October 1974}

Type

Production Forecasts:

General Forecasts:

Special Forecasts

Dther Requests:

Publications Distributed:

Number of Calls Processed by Code-A-Phone:

TOTAL SERVICE ACTIONS:
No. Made \% Reliability

93

87.6

62

92.7

148

95.9 
Number

OFF-SITE DISTRIBUTION

1-3 USAEC, Washington-Division of Production

$4 \quad$ USAEC Headquarters

J. L. Liverman, AGMBER

5-6 Technical Information Center, 0ak Ridge Tennessee

7 Savannah River AEC Operations Office

8-9 E. I. de Pont de Nemours \& Company Savannah River Laboratory

10 AEC Idaho Operations Office K. K. Kennedy

11 Allied Chemical Corporation, Idaho Falls

ON-SITE DISTRIBUTION

AEC Richland Operations Office

0 . J. Elgert

A. G. Fremling

P. G. Holsted

B. J. Melton

P. G. Rhoades

R. B. St. John

F. R. Standerfer

United Nuclear Industries, Inc.

19 J. R. Bolliger

20 P. A. Carlson

21 R. E. Dunn

22 A. E. Engler

23 A. R. Maguire

24 N. R. Miller

25 R. S. Peterson

26 R. K. Robinson

27 H. F. Tew

\section{Atlantic Richfield Company}

28

29

30

31
F. E. Backman

D. J. Brown

L. E. Bruns

G. Burton, Jr.
Atlantic Richfield Company (cont.)

32 R. E. Felt

33 R. D. Fox

34 R. G. Geier

35 D. G. Harlow

36 W. M. Harty

37 H. H. Hopkins

38 W. P. Ingalls

39 R. E. Isaacson

$40 \quad H . F$. Jensen

4.1 L. M. Knights

42 C. W. Malody

43 T. R. McKenzie

44 B. J. McMurray

45 G. A. Nicholson

46 G. C. Oberg

47 J. V. Panesko

48 K. R. Price

49 W. W. Schulz

50 H. P. Shaw

51 A. E. Smith

52 R. E. Smith

53 G. T. Stocking

54 M. J. Szulinski

55 W. J. Van Slyke

56 D. D. Wodrich 
Westinghouse Hanford Company

57 G. J. Alkire

$58 \quad A, G$. Blasewitz

Battelie-Northwest

59 R。E. Burns

60 E. D. Clayton

61 J. P. Corley

62 J.R. El yason

63 R. F. Foster

64 T. R. Gar'land

65 K. M. Harmon

66 H. L. Henry

67 G. Jansen

68 J. H. Jarrett

$69 \mathrm{~J}, \mathrm{~L}$. McElroy

70 R. E. Nightingale

71 D. E. Olesen

72 W. D. Richmond

73 W. H. Rickard

74 R. C. Routson

75 L. C. Schwendiman

76 G. A. Sehme 1

77 A. J. Shuickrow

78 C. L. Simpson

79 W. G. N, SI inn

80 R。 1. Smith

81 H. H. Van Tuyl

82 B. E. Vaughan

83 D. G. Watson

84 R. E. Wildung

85 R. K. Woodruff

$86 \mathrm{~J}$. R. Young

87-89 Technical Information Files

90 Technical Publications 